\title{
Silver spoons and black mobility: The white South African economic elite and its implications for the upward mobility of blacks
}

\author{
P.Human and Linda Human* \\ Oraduate School of Business, Untversity of Cape Town, Private Bag, Rondeboech, 7700 Republic of South Africa
}

Raceived 19 November 1906; scoppeed 9 January 1907

\begin{abstract}
Implicit in any discussion of the concentration of oconomic power is the assumption that the South African economy is dominated by a coherent and cchesive white economic ellite. Two separate but complementary perspectives can be used to explain this phenomenon. The classical social mobility perspective argues that elites in the western world have tended to reproduce themselves. By a process of 'social closure' which involves the use of two main exclusionary devices - property and credentials - groups attempt to optimize their own rewards by restricting access to resources and opportunitites to 'insiders'. The related economic argument suggests that higher profit is achieved through a hegemonic kind of social organization which is sufficiently stable to facilitate the exchange of information and expertise between corporations, thus decreasing risk. The sociological and economic perspectives are analysed using data pertaining to South Africa's business elite. It is found that the sociological perspective is valid but that the economic perspective does not hold ground. The implications of exclusionary closure by the white business elite for both black mobility and the transfer of capital to black people are discussed.
\end{abstract}

In enige bespreking van die konsentrasie van ekonomiese mag word aanvaar dat die Suid-Afrikaanse ekonomie gedomineer word deur 'n koherente blanke ekonomiese elite. Daar bestaan twee afsonderlike maar komplementere verklarende perspektiewe wat gebruik kan word ten opsigte van hierdie verskynsel. Die klassieke sosialemobiliteit-perspektief gaan van die standpunt uit dat elites in die Westerse samelewings hulself reproduseer. Deur gebruik te maak van 'n proses van 'sosiale sluiting', wat twee uitsluitingsmeganismes, naamlik: eiendom en aanneemlikheid bevat, poog groepe om hul eie belange te optimiseer deur 'buitestanders' se toegang tot bronne en geleenthede te beperk. Die verbandhoudende ekonomiese argument redeneer dat hoer profyte gerealiseer kan word deur middel van 'n hegemoniese tipe van sosiale organisasie wat stabiel genoeg is om die uitruiling van inligting en deskundigheid tussen korporasies moontlik te maak en aldus risiko te verminder. Die sosiologiese en ekonomiese perspektiewe word geanaliseer aan die hand van gegewens betreffende die Suld-Afrikaanse ekonomiese elite. Ons bevind dat die sosiologiese perspektief geldig blyk te wees terwyl die ekonomiese argument nie steek hou nie. Die tmplikasies van ekslusiewe sluiting deur die blanke ekonomiese elite ten opsigte van swart mobiliteit en die cordrag van kapitaal na swartmense word bespreek.

- To whom correspondence should be addressed

\section{Introduction}

Implicit in any discussion of the concentration of economic power is the assumption that the South African economy is dominated by a coherent and cohesive white economic elite. Two separate but complementary perspectives can be used to explain this phenomenon. The classical sociological perspective of the social reproduction of existing relations of power suggests that elites in the majority of countries of the western world have tended to reproduce themselves. By a process of 'social closure', which involves the use of two main exclusionary devices - property and credentials - groups attempt to optimize their own rewards by restricting access to resources and opportunities to a limited number of people whom they regard as 'eligible' (Parkin, 1979). The ability of the few to govern the many, economically and politically, depends heavily on the process of 'exclusionary closure' by means of which property ownership and the (interlinked) possession of educational qualifications result in internal cohesion or group hegemony.

The second perspective, a related economic argument, regards the dominance of a coherent elite as a pragmatic means to a self-interested end. The end of higher profit is achieved through a kind of social organization which is sufficiently stable to facilitate the exchange of in- formation and expertise between corporations, thus decreasing risk.

The literature on the concentration of economic power in South Africa (Du Plessis, 1978; Savage, 1984) has contributed significantly to our understanding of the nature of power relations in our society. Such studies are, however, generally descriptive and concentrate on the institutional nature of power rather than on that of particular individuals. The description of power relations in institutional terms - Anglo-American controls 52,5\% of share capital or $5 \%$ of firms control over $63 \%$ of turnover - provides a 'faceless' or depersonalized conception of power relations which obscures the fact that particular individuals, or, more specifically, an elite group of individuals, wield a significant amount of personal power. These individuals shape and direct their business organizations; the organization is merely the instrument of those who own and control it in order to, inter alia, further their own interests. These interests include the perpetuation of family power via the transfer of property and credentials to their children.

In the South African corporate world, economic power has historically been the preserve of two dominant groups, namely, the English and Afrikans business elites (van der Merwe, Ashley, Chorton \& Huber, 
1974). These white elites have historically restricted access to resources (capital/property) and opportunities (credentials) particularly by isolating race and by justifying racial exclusion, they have created an economy in which the access of blacks to both property and credentials has been severely restricted.

In recent years, skills shortages and socio-political developments have led to an increased lip-service being paid to the need for so-called 'black advancement' into managerial ranks. More recently, attention has also been paid to the need for blacks to possess a stake in private enterprise through the transfer of venture capital. We are thus witnessing a call for strategies to break through exclusionary closure by means of the transfer of property and credentials to blacks. This call, in turn, presupposes that this kind of breakthrough can, in fact, be made and that the concentration of economic power and credentials in predominantly white hands can be diluted.

The purpose of this article is to investigate the economic and sociological perspectives as they relate to the white elites in South African business circles. This analysis in tum will pave the way for a tentative discussion of the possibility of inroads being made by black people into the South African business elite.

\section{Social mobility and ellte formation}

The first national sample of mobility data was collected by David Glass and his colleagues at the London School of Economics in 1949. Glass looked at a random sample of 10000 adult civilians aged 18 years and over, resident in England, Scotland and Wales. Glass's work has subsequently borne the brunt of heavy criticism but, in its time, his work constituted a major pioneering study from which a large number of authors in various countries have drawn inspiration (Heath, 1981).

The main conclusions which Glass drew from his data were that Britain exhibited a considerable amount of relatively short-range mobility together with a higher degree of rigidity and self-recruitment at the extremes. Rigidity and self-recruitment were particularly evident at the upper levels of the social structure where there existed the strongest tendency for sons to follow in their fathers' footsteps and enter broadly comparable occupations (Glass, 1954).

Analysing Glass's data some years later, Westergaard \& Resler (1975) point out that capitalism does allow a certain degree of fluidity of circulation but that high rates of social mobility can, at the same time, be compatible with gross inequalities of opportunity. In other words, although many children from high-status origins may be be downwardly mobile compared with their fathers, these children may still on average have a much better chance than their working class contemporaries of getting high-status jobs themselves. Fluid circulation is not necessarily synonymous with free circulation. Inequality of condition sets marked limits to individual opportunities and risks of ascent and descent. In most countries of western Europe, occupants of specific rungs on the class ladder are far more likely to stay at roughly the same level as their fathers than they would be if there was 'perfect mobility'. This contention, is, moreover, particularly relevant to those born at or near the top of the scale (Heath, 1981).

Glass's (1954) analysis of mobility in Britain was quickly followed by other investigations in Denmark, Sweden and Japan. Lipset \& Bendix (1959) subsequently undertook secondary analyses of data from nine industrialized societies, namely, France, Germany, Sweden, Switzerland, USA, Japan, Great Britain, Denmark and Italy.

Virtually all nine countries exhibited similar high rates of total vertical mobility, and the USA proved to be no more open than the traditional societies of Europe. Factors which varied between societies - such as historical background, cultural patterns and national values clearly had to be rejected and common features sought.

Heath (1981: 221-22), however, argues that, among western societies, USA, Canada and Sweden have the highest de facto rates of social mobility but that, once the shape and rate of change of the occupational structure are taken into account, Australia and Sweden come to the fore whilst USA, Canada and Britain are consigned to an intermediate level.

Countries which have been subjected to long periods of right-wing or fascist rule, such as West Germany, Italy, Spain, Japan and France proved to be more closed than expected on the basis of their occupational structures.

On the other hand, the 'distinctive features of mobility patterns in the communist block are the very high rates of inflow into elite and white-collar occupations. These may be due more to their rapid industrialization than to any permanent features of their societies, but their consequences could be real enough for all that. The broad social mix within their elites, with large numbers drawn from manual and farm backgrounds, may well have important implications for the character and culture of these societies' (Heath, 1981: 221).

Whether or not the socialist societies will converge to a North American pattern at some later date remains an issue over which there is some controversy.

The most recent large-scale study of mobility in Britain was undertaken by a group of sociologists from Oxford University in 1972. Their sample consisted of 10 000 adult males who constituted a representative crosssection of all males aged 20 to 64 years and resident in England and Wales in 1972. These respondents were asked to give outlines of their own occupational and educational biographies as well as basic biographical information about their fathers, mothers, wives, brothers and friends.

Factual material only was collected although in a follow-up study in 1974, some additional data were collected on the subjective experiences of a limited number of the original respondents.

The Oxford study was strongly criticized for its omission of women, although it is a moot point whether or not women should be included in mobility studies. As many women are primarily involved in domestic labour, the man's job constitutes the major articulation between the family and the class structure. 
In other words, many married women do not work and many that do, do not oocupy full-time jobs. Moreover, the positions they hold are usually similar or lower than those of their husbands so that the dominance of the latter's class position is rarely affected.

On the other hand, although the occupations of many married women are part-time, they often affect quite crucially the overall standard of living of their family. Moreover, the relationship between a woman's social origins and her occupational position is of interest in its own right. This is particularly the case in South Africa where the greater part of black mobility in recent years has been amongst black women (see Human \& Hofmeyr, 1985).

The Oxford social mobility study resulted in a large number of complex and interrelated findings. One of the most important findings, however, is that a 'man from a working-class home has about one chance in fifteen hundred of getting into Who's Who; the man from a whitecollar background has perhaps one chance in five hundred; the man from the higher professional and managerial home has one chance in two hundred; but the man from the elite home has a one-in-five chance' (Heath, 1981: 77).

Heath (1981: 191) later states that 'Education has come to play an increasing role in the transmission of status (loosely defined) from father to son; the direct influence of social origins - whether through patronage, nepotism, inheritance or some other mechanism - on occupational attainment has declined, but simultaneously its indirect influence via the educational system has increased as family background has become more closely linked to educational success and failure'.

Research into trends in elite recruitment is patchy in both the UK and Western Europe. Be that as it may, evidence from the UK suggests that the elite has tended to become more open although the slow pace and lack of consistency of pace at which this has taken place is perhaps the most notable feature. The reason for this is, of course that the elite is not a homogeneous one with greater openness occurring more easily within some sectors than others. For example, whereas in the civil service increasing openness has led to the replacement of ascription by, to a limited extent, achievement, in the other sectors of the elite this movement is not so clearcut. Thus, although the individual entrepreneur has been squeezed out by the concentration of industry and the spread of large-scale bureaucracies, families remain a force in British industry. Within the city, moreover, there has been very little movement from ascription to achievement and exclusivity prevails (Heath, 1981: 8896). Put another way, the movement from ascription to achievement is neither wholly myth or wholly fact: 'children from privileged backgrounds have substantial, indeed grotesque, advantages in the competition for elite positions, but when they take their place in the elite they may find that they are outnumbered by men from humbler origins' (Heath, 1981: 76-77). According to the Oxford Social Mobility group, the great inequalities of opportunity are not those between children whose fathers are white-collar and blue-collar, in other words, between the manual-non-manual divide, but rather between the elite and non-elite. Those born into the elite have hugely disproportionate chances of reaching an elite position themselves (Heath, 1981: 77).

\section{Soclal mobility in South Africa}

Very little work of a systematic nature has been undertaken on social mobility in South Africa. However, the historical development of South Africa has led to a situation in which whites generally occupy the top half of the occupational hierarchy and blacks the unskilled posts.

Indeed the overall occupational structure remains one in which whites dominate the upper categories of employment out of all proportion to their participation in the labour force and the other race groups, and in particular blacks, are over-represented in the lower categories of employment.

Shifts have and are taking place in the occupational structure, however, as greater numbers of blacks move into higher categories of employment. For all three of the 'non-white' racial groups, movement has taken place mainly in the sales and clerical occupations.

It is, moreover, the female members of the black, Asian and coloured groups that are making the greatest in-roads into these two occupational categories. Blacks remain under-represented in professional and managerial positions and their proportional participation has been slow to increase (Human \& Hofmeyr, 1985).

Although large and dramatic percentage increases in black (and especially female) participation in certain occupational categories have been recorded, absolute numbers and participation rates - relative to overall participation in the labour force - remain small. A further qualification which must be borne in mind is that much of the 'black' increase in professional participation is due to the large and increasing numbers of teachers and nurses.

For women, this represents employment in the traditional female occupations and, for the black group as a whole, employment in the lower status, lower paying professions. At the same time, large but declining proportions of coloureds and blacks (particularly men) are employed in the agricultural sector and small increases have been recorded with regard to black participation in the artisan/apprentice category (Human \& Hofmeyr, 1985).

There is more upward than downward intergenerational mobility amongst blacks. Such mobility is taking place amongst those from unskilled origins who obtain jobs in the clerical, blue-collar, technical and skilled manual occupational categories. Schneier (1983) argues that this movement has been due to an increased demand for employees in these occupations and a contraction in the demand for unskilled labour. There also exists a fairly high degree of intergenerational occupation stability.

Post-school education and first job were shown to be the most important determinants of occupational attainment. Legal status was a|so positively and fairly strongly associated with both education and occupation; there 
was less intergenerational upward mobility amongst those with 'weak' legal status (Schneier, 1983).

The occupational structure which currently exists in South Africa is the result of a history of racial exclusion whereby whites have employed a system of separate development to deny access to property and credentials to blacks. In other words, legal, social and political restrictions have impeded the ownership of property and of businesses by blacks and have also resulted in unequal educational provision. Thus, in 1985, 70\% of the economically active population with Standard 10 or more was white; $97 \%$ of managers of Patterson ' $D$ ' grade or of equivalent or higher positions were white and well over $90 \%$ of all engineers. In terms of economic power, McGrath (1977: 22) estimates that the share of personal income of whites was $71,2 \%$ in 1970 . The black share was $19,8 \%$. The top $5 \%$ of wealth owners (property ownership, savings, investments), who were overwhelmingly white, owned $88 \%$ of personally owned wealth. In 1980, the Racial Disparity Ratio of Income for blacks and whites was $12,9: 1$.

The only study of the white South African elite appears to be that of van der Merwe et al (1974) who defined the elite as those persons at the top of the white occupational hierarchy. Thus, individuals from the political, religious, judicial and public sectors were included along with individuals from the business sector. According to van der Merwe et al (1974: 24), because South Africa is a rapidly industrializing country, many elite members have risen to prominence from relatively humble beginnings. Thus, many members of the elite are outstanding citizens rather than members of a distinct privileged class. (This, of course, begs the question of whether or not their children will become part of a privileged class their parents created.) Van der Merwe et al's elite were generally older, better educated and eamed more (because of their occupational positions) than the general public, findings which follow-on logically from their elite status. Afrikaners were under-represented and English over-represented. Afrikaners were viewed as 'modernizing'; as moving from a rural to an urban base and displaying some anglicization. The Afrikaners displayed far more cohesion on a political and values level than the separate and distinct English-speaking elite.

It would thus appear that within the South African capitalist system, certain mobility patterns can be speculated upon. Firstly, we have the exclusion of blacks on racial grounds, with access to social mobility generally being denied to all but the most tenacious and historically the most politically malleable black people. Within the white social group itself, there is a degree of fluidity of circulation side by side with inequalities of opportunity. In other words, although some children from high-status origins may be downwardly mobile compared with their fathers, these children may still on average have a much better chance than their lower class contemporaries of getting high-status jobs themselves. This may apply for both the English and Afrikaans groups. With the opening of the business elite through economic growth, Afrikaans businessmen were able to find a niche. Although many of those taking a place in the elite were from rural areas and may have been comparatively economically underprivileged, they still may have been individuals whose already existent elite status, whose levels of education, whose perceptions of the value of education, or whose inherent entrepreneurial talent dis. tinguished them from other Afrikaners in similar circum. stances. It would appear to be misguided to regard rural Afrikaners during the first half of this century as a homogeneous group; rather, they were a group with a specific social structure which perpetuated itself through time. The chances of rural Afrikaners becoming part of the business elite were probably not random but rather dictated by a social structure with its own existing elite. Rosearchers like van der Merwe et al. (1974) have failed to make this explicit.

Be that as it may, it would appear that the children of the white elite - be they English or Afrikaans - have a greater chance of reaching similar positions themselves than white children of more lowly social origins. Transmission of status is directly influenced by patronage, nepotism and inheritance and indirectly influenced by the provision of elite education. We will return to these propositions below.

\section{The economic perspective}

According to Allan (1974: 393), interorganizational elite cooptation, in the form of interlocking corporate directorates, can be regarded as a strategy of cooperation between businesses employed to reduce sources of uncertainty in the environments in which they must function. 'Specifically, corporate interlocking is a means of anticipating or controlling sources of uncertainty stemming from the potentially disruptive unilateral actions of other corporations' (Allan, 1974: 392). The primary function of corporate interlocking appears to be the exchange of information and of expertise. It also provides communication and liaison between corporations which are to some extent dependent on each other. An example here is the bank director who is asked to join the board of an industrial corporation both because of his knowledge of finance and his access to financial information as well as his ability to facilitate financial transactions (Allan, 1974: 395). Although empirical research in this field is limited Allan's (1974) own research indicates that 'the size of a corporation is directly related to the frequency of interlocking in general even controlling for the size of its directorate' (p. 393). Financial corporations appear to maintain more interlocks than non-financial corporations in view of the importance of capital as a resource. 'Contrary to the theory, there is no clear relationship between such organizational characteristics as capital intensity and growth and the frequency of interlocking with financial corporations: moreover, there is even a significant negative relationship between dependency on external debt obligations and frequency of financial interlocking' (Allan, 1974: 393). Again contrary to the theory, the frequency of interlocking with financial corporations has increased with time. 
Let us now examine the sociological and economic perspectives in relation to the white business elite and elicit conclusions with respect to the upward mobility of black people.

\section{Research method}

Our units of analysis are companies listed on the Johannesburg Stock Exchange. Our data bases were McGregor's Who Owns Whom (1984), the Sunday Times Top 100 Companies Survey (1985) and the August 1984 Johannesburg Stock Exchange Handbook. The information collected for each listed company consisted of the number of directors on the board; the number of multiple directors (directors who also serve on the boards of one or more other companies) per board of directors; the ordinary share capital of each company; the ultimate controlling shareholder as defined by McGregor (1984); the Sectoral Classification of the company; and the performance rating of the company.

The performance rating of the Sunday Times Top 100 Companies Survey was used. Performance was measured as the capital gain on a share over a five-year time period by subtracting the opening price from the closing price. To this difference was added all dividends paid plus interest at $12 \%$ a year on those dividends. That gives us a cash return on investment for the shareholder. This return was related to the original investment to arrive at an average annual compound growth rate over five years. This determined the performance ratings of the companies. This measurement of performance is, admittedly, biased towards the interests of the shareholder. It is however well-suited to our purpose because it is exactly such a measure of performance which would be used by companies as an economic rationale for the formation and justification of inter-corporation cooperation.

Our operationalized definition of elitist tendencies is the network of directors found within a collectivity of companies through the existence of multiple directorships. Directors are legally vested with the control and management responsibilities of a company. 'The company itself cannot act in its own person, for it has no person; it can only act through directors' (Hahlo, 1984: 355). Directors are, in contrast to managers, required by law; their functions are defined by law and they represent the interests of the shareholders. Managers are appointed as employees by the directors to act on their behalf. Directors have then, in theory, far more power than managers to influence the behaviour of the company if they wish to do so and they are also structurally better positioned to organize the company's relationships with the extemal environment. It is this latter function in which we are most interested; the network of cooperation and collusion existing between companies as expressed by the existence of multiple directorships.

\section{Multiple directorates}

The average number of multiple directorates per board of directors of listed companies was 5,6 . The average size of the boards was $\mathbf{8 , 5}$. This means that an average of
Table 1 Mean number of multiple directorates and percentage multiple directors per board by sector

\begin{tabular}{lcc}
\hline & $\begin{array}{c}\text { Mukiple directors } \\
\text { \% of board }\end{array}$ & $\begin{array}{c}\text { Mean number of } \\
\text { multiple directors }\end{array}$ \\
\hline All & 63,2 & $5,6(N=436)$ \\
Financial & 69,3 & $6,3(N=91)$ \\
Industrial & 56,1 & $4,8(N=268)$ \\
Mining & 80,4 & $7,4(N=77)$ \\
\hline
\end{tabular}

$F=20,34(P=0,001) F=28,84(P=0,001)$

$65,9 \%$ of board members also serve on the boards of one or more other companies. This percentage varies between 92,0\% (Gold Mining) and 35,7\% (Building and Construction). The sectors in which a high percentage (between $70 \%$ and $92,0 \%$ ) of multiple directors per board were found are Gold Mining, Tobacco and Match, Mining-Holding, Mining Houses, Financial Investment Trusts, Beverages and Hotels, Sugar, Diamonds and Financial Property. Those with relatively low percentages $(35,7 \%-52,8 \%)$ are Building and Construction, Pharmaceuticals, Transport, Chemicals and Oils, Engineering, Paper and Packaging and Electronics.

A significant difference was found to exist between the number of multiple directors in different broad sectorial categories.

The greatest degree of multiple directorates was found in the mining sector. This would appear to be a result of the tendency within the large mining corporations to have a high degree of intra-corporation cooperation. This cooperation is reflected in the high degree of multiple directorates found within a group. In the case of Anglo American, which, in turn, dominates this sector, we find that the 27 directors on the board of the Anglo American Corporation share between them a total of 225 directorates. Only 35 of those directorates are related to companies not ultimately controlled by Anglo American. The control network of the Anglo American group on the board of directorates is thus very cohesive and tight. The same pattern is found for other large corporate groupings such as Sanlam (11 directors share between them 57 directorates of which only 15 fall outside the ambit of the group) and, to a lesser extent, Old Mutual.

In Table 2 we have listed the directors who have nine or more directorates. From this table it can be seen that it includes most of the 'captains of industry'. It would also appear that this group serves on the boards of the largest companies, which, conversely means that the extent of multiple directorates is less profound in the smaller sized companies. This fact is also substantiated by a significant correlation coefficient $(r=0,38 ; p=$ $0,001)$ between ordinary share capital and the number of multiple directorates (see Table 5).

The structure of the collectivity of listed companies in terms of size (as measured by ondinary share capital) is one in which a few large companies dominate the whole 
Table 2 Multiple directorates - JSE 1985/6

\begin{tabular}{|c|c|c|}
\hline $\begin{array}{l}\text { Director's } \\
\text { nume }\end{array}$ & $\begin{array}{c}\text { Main } \\
\text { representation }\end{array}$ & $\begin{array}{l}\text { Number of } \\
\text { directorships }\end{array}$ \\
\hline P'vitt, E. & Sanlam & 24 \\
\hline Hersov, B.E. & Anglovaal & 22 \\
\hline Fritz, J.C. & Sanlam & 21 \\
\hline King, M.W. & Anglo American & 21 \\
\hline Netscher, C.R. & Anglo American & 21 \\
\hline Gush, E.P. & Anglo American & 20 \\
\hline Menell, C.S. & Anglovaal & 20 \\
\hline Crowe, D.J. & Angloval & 19 \\
\hline Smith, H.A. & Sanlam & 19 \\
\hline Ogilvie Thompson, J. & Anglo American & 17 \\
\hline De Beer, T.L. & Sanlam & 16 \\
\hline Fenton, C.T. & Anglo American & 16 \\
\hline Relly, G.W.H. & Anglo American & 16 \\
\hline Boustred, W.G. & Anglo American & 15 \\
\hline Waddell, G.H. & Anglo American & 15 \\
\hline Clewlow, W.A.M. & SA MutualBarlows & 14 \\
\hline Oppenheimer, N.F. & Anglo American & 14 \\
\hline Sunter, C.L. & Anglo American & 14 \\
\hline Evans, W.B. & Sanlam & 12 \\
\hline Van der Horst, J.G. & SA Mutual & 12 \\
\hline Van Rooyen, B.R. & & 12 \\
\hline Daling, M.H. & Sanlam & 11 \\
\hline Landau, $\mathbf{B}$. & Senlam & 11 \\
\hline Pretorius, T.L. & Anglo/Goldfields & 11 \\
\hline Robertze, J.C. & Anglovaal & 11 \\
\hline Watt, D.T. & SA Mutual/Barlows & 11 \\
\hline Galombik, A. & Mobile & 10 \\
\hline Gnodde, A.M.D. & Anglo/Coldfields & 10 \\
\hline Gondon, D. & Liberty & 10 \\
\hline Kardol, B. & SA Mutual/Barlows & 10 \\
\hline King, M.E. & Sanlam/Kirsh & 10 \\
\hline Lawrie, W.R. & Anglo American & 10 \\
\hline Munro, A.H. & Anglo-Goldfields & 10 \\
\hline Rapp, $\mathbf{M}$ & Liberty & 10 \\
\hline Rood, T.B. & Pikand Group & 10 \\
\hline Simchowitz, $\mathbf{M}$. & Waicor & 10 \\
\hline Wright, J.A. & Anglo American & 10 \\
\hline Beck, W.F.de la H. & Sanlam & 9 \\
\hline Bloom, A.H. & Anglo American & 9 \\
\hline Ferreira, C.G. & Sanlam & 9 \\
\hline Fuller-Good, M.R. & Anglo American & 9 \\
\hline Glatt, M.B. & Waicor & 9 \\
\hline Hofmeyr, M.B. & Anglo American & 9 \\
\hline Knobbs, C.G. & SA MutualBarlows & 9 \\
\hline Muller, G.S. & SA Mutual/Nedbank & 9 \\
\hline Pickard, J.A.J. & Pickard Group & 9 \\
\hline Rosholt, A.M. & SA MutualBarlows & 9 \\
\hline Witson, R.A.D. & Angloveal & 9 \\
\hline Young, G.S. & Anglo American & 9 \\
\hline
\end{tabular}

Source MoGregor (1986)

collectivity of companies. A mere six groups of companies (Anglo-American Corporation, Sanlam, SA Mutual, Rembrandt, Liberty and Anglovaal) control $85,1 \%$ of share capital. This skewed distribution of
Table 3 Distribution of directorates (1984)

\begin{tabular}{lcr}
\hline $\begin{array}{l}\text { Number of } \\
\text { directorates }\end{array}$ & $\begin{array}{c}\text { Number of } \\
\text { directors }\end{array}$ & $\%$ \\
\hline 1 & 1845 & 72,7 \\
2 & 364 & 14,3 \\
3 & 127 & 5,0 \\
4 & 57 & 2,2 \\
5 & 43 & 1,7 \\
6 & 28 & 1,2 \\
$7-33$ & 75 & 2,9 \\
& ---- & --- \\
& 2539 & 100,0 \\
\hline
\end{tabular}

Table 4 Control of market capitalization and number of companies (1984)

\begin{tabular}{lcc}
\hline Controlled by & Capitalization & No. of companies \\
\hline Anglo American & 35,3 & 76 \\
Sanlam & 11,3 & 37 \\
International & 9,2 & 61 \\
Directors & 8,3 & 109 \\
SA Mutual & 7,3 & 29 \\
Families & 6,7 & 52 \\
Person & 5,3 & 14 \\
Rembrandt & 3,6 & 6 \\
Others & 13,0 & 90 \\
& --- & --- \\
. & 100,0 & 474 \\
\hline
\end{tabular}

control is also reflected in the structure of directorates.

This distribution would, at first glance, appear 'democratic'. We should, however, remember that it is the $2,9 \%$ of directors (the $7-33$ category) who control the largest companies; they are almost all related to the 'big six' who control $85,1 \%$ of wealth on the stock exchange (as can be seen from Table 2).

The masking of people behind institutions found in the institutional analysis of the concentration of economic power leaves us with a skewed, though not invalid, picture of ultimate control of listed companies. McGregor's (1986) analysis, for example, ignored the fact that the large holding companies such as Anglo-American Corporation, Liberty Life, Anglovaal, Rembrandt and Altech, are controlled by individuals or families. If one then creates categories for persons and families in one's list of ultimate control and subtracts the ordinary share capital represented by these holding companies controlled directly by persons or family interests from the total share capital of the groups, the picture changes somewhat.

It is clear that both individual persons and families still play a significant role in the South African economy, as well as possess enormous wealth. 
Some further findings on the nature of multiple directorates are, inter alia, the larger the company, the larger the board of directors and the higher the percentage of multiple directorates. The average percentage of multiple directorates per board size of Afrikaans-dominated companies $(76,7 \%)$ is significantly higher than in the case of English-dominated companies $(66,2 \%)$ and 'mixed' companies $(63,6 \%)$. This would suggest more cohesive and exclusive elite networks in the case of the Afrikaans sector than in the case of the English and mixed sector. The Anglo American group would appear to have the highest percentage of multiple directorates per board $(74,5 \%)$ followed by State-controlled companies $(72,4 \%)$, families $(69,4 \%)$, Sanlam $(67,7 \%)$, institutional control $(64,8 \%)$, SA Mutual $(63,4 \%)$ and Rembrandt $(62,6 \%)$.

\section{A blographical profile of the economic ellte}

A sample of 45 directors was drawn. This sample consists of 35 directors from our list of multiple directors (Table 2) and 15 other directors from the largest listed companies. We used the Who's Who of Southern Africa (1984) as our biographical source. Some of our multiple directors from Table 2 are not included in the Who's Who, other notable personalities such as F.J.du Plessis (Sanlam) and C.J.W. Ball (Barclays) are also omitted. The sample, nevertheless, includes the bulk of the chairmen or managing directors of the largest corporations in South Africa.

Almost two out of every five $(40,0 \%)$ of our sample attended a private school, inter alia, St Johns (Johannesburg), Diocesan College (Rondebosch), St. Andrews (Grahamstown), Hilton College, Michael House (Natal). Only $5(11,1 \%)$ went to, what one could call, 'average' state schools; the majority $(\mathbf{4 8 , 9 \% )}$ attended the more elite state schools such as Grey College (Bloemfontein), Pretoria Boys High, Afrikaans Seuns Hoèr, Paarl Gymnasium, Volksskool (Heidelberg) and Jeppe High School.

A total of 79 degrees, of which nine were honorary were conferred by universities on the sample of directors. Seventeen $(29,3 \%)$ studied at the University of the Witwatersrand followed by 11 (nearly a fifth) who studied at Oxford or Cambridge. Nine directors attended American Business Schools such as Harvard, Stanford and Wharton. Nine directors attended Afrikaans Universities (five Pretoria, three Stellenbosch and one the University of the Orange Free State).

The educational background of this small sample of people is highly homogeneous if one compares it to the educational backgrounds of any population sample drawn randomly. The 'old school-tie' phenomenon is very much in evidence and the quantity and quality of education received by the sample contrast sharply with those of the population as a whole. This would suggest that these directors have had an enormous 'pre-market' advantage in getting to the positions they ended up in. The foundations for the socialization of new members of the economic elite are firmly laid in the private and exclusive educational system.
But it is not only the educational backgrounds of this sample that ensured its pre-market advantage. It would also appear that the majority of our directors came from homes in which a high quality of education was valued and, perhaps more importantly, could be afforded. Although we have no data to support this hypothesis, the concentration on exclusive educational institutions suggests strongly that this is the case.

Sixteen out of the $\mathbf{4 5}$ directors were born in Johannesburg from families, the majority of which, it appears, were already established members of the upper classes. Another nine were bom in Europe and 13 in the rural areas of South Africa. Of those born in the rural areas, nine are Afrikaans-speaking (Rupert, Wessels, de la Harp Beck, Human, van der Horst, etc); only three Afrikaners from our sample were born in cities. The 'mobility paths' of the English-speaking and the Afrikaans-speaking directors would appear to differ sharply. The Afrikaans-speaking directors came from the rural areas and are all relative 'newcomers' to the South African eccnomic elite whilst many of the Englishspeaking directors would appear to have been brought up within the economic elite. This does not, however, mean that the Afrikaans directors were not part of their own elite in the rural areas. Indeed evidence suggests that the Afrikaans directors were members of a rural Afrikaans elite prior to their entry into the business elite. The members of the economic elite would appear to have very similar life styles. The overwhelming majority of them live in Sandton, Illovo, Sandhurst, Houghton, Parktown, and Melrose in Johannesburg (26), in Constantia or Bishopscourt in Cape Town, or Waterkloof or Lynwood in Pretoria. They belong collectively to 95 clubs, inter alia, Rand, Country, Inanda, Wanderers, City and Civil Service, Whites London Recreation Club, Hawks, Chamber of Mines, Kimberley, Here XVII, Houghton, Club RSA, River, Ancient St. Andrews. Similarities in life style (occupation, education and recreation) suggest that the coherence and cohesion of the elite is maintained on both a social and occupational level.

From this rather small sample of the economic elite it is apparent that there would appear to be enough ground to assume that the sociological explanation of elites is indeed valid. The penetration of the less privileged into this elite would seem not to be easily attained. The Afrikaner elite appears not to have penetrated the English elite, but rather to have created its own elite. It should however be emphasized that the EnglishAfrikaans split would appear to have become less pronounced; the SA Mutual, for example, displays a 'mixed' or 'South African' flavour in a purely 'white' sense, of course.

\section{Financial performance and multiple directorates}

No consistent or strong relationship could be found to exist between performance rating and multiple directors. In Table 5 the correlation coefficients between board size, multiple directors per board, ondinary share capital, 
Table 5 The relationship between performance rating and multiple directorates

\begin{tabular}{lccccc}
\hline & $\begin{array}{c}\text { Perform- } \\
\text { ance } \\
\text { rating }\end{array}$ & $\begin{array}{c}\text { Share } \\
\text { capital }\end{array}$ & $\begin{array}{c}\text { Board } \\
\text { sixe }\end{array}$ & $\begin{array}{c}\text { Multiple } \\
\text { direct- } \\
\text { orates }\end{array}$ & $\begin{array}{c}\text { Ratio } \\
\text { multiple } \\
\text { directorates } \\
\text { Board }\end{array}$ \\
\hline $\begin{array}{l}\text { Performance } \\
\text { Rating }\end{array}$ & - & & & & \\
$\begin{array}{l}\text { Share capital } \\
\text { Board size }\end{array}$ & 0,004 & - & & \\
$\begin{array}{l}\text { Multiple } \\
\text { Directorates }\end{array}$ & $-0,070$ & $0,438^{*}$ & - & \\
Ratio multiple & $0,110^{*}$ & $0,385^{*}$ & $0,707^{*}$ & \\
Dir/Board & $-0,095^{*}$ & $0,143^{*}$ & $0,161^{*}$ & $0,667^{*}$ \\
\hline
\end{tabular}

$P<0,05 . N=350$

the ratio of multiple directors per board and performance rating are presented.

The size of a company (as measured by its ordinary share capital) would seem to be unrelated to its performance. Size does, however, relate fairly strongly to the size of the board of directors and the number of multiple directorates. Although statistically significant correlation coefficients were established between performance and the absolute number of multiple directors as well as between the ratio of multiple directors per board, those correlations are not meaningful. The large $\boldsymbol{N}(350)$ would almost always produce statistically significant results. Our data suggest that none of the variables included in this study relate meaningfully to performance.

Table 6 Mean rating' by type of control

\begin{tabular}{lc}
\hline Controlled by & Mean rating of group \\
\hline State & 127,2 \\
Inatitutions & 130,8 \\
Families & 144,4 \\
SA Mutual & 159,5 \\
Rembrandt & 160,6 \\
Directors & 183,8 \\
International & 187,5 \\
Anglo American & 199,6 \\
Sanlam & 211,2 \\
Total population & 178,1
\end{tabular}

"Ratings varied between 1 (the best performer) and 358 (the worx performer.)

No clear picture could be arrived at when performance ratings were related to type of control.

It is however clear that the two top 'dinosaurs' of the South African economy performed least well of the population under study. At the same time, however, it was found that state-controlled companies and companies controlled by institutions performed well. None of the other variables in the study offered explanations for this finding. It must therefore be deduced that the performance of a company is not directly related to the type of control, the number of multiple directors on its board nor the size of the company, but rather to other factors.

A sectorial analysis of performance rating would seem to suggest some relationship between performance and the type of business of the company. Eight of the thirteen worst performing sectors were sectors related to the primary sectors (Gold, Diamonds, Sugar, Coal, Metals and Minerals) or heavy industry (Steel and Allied, Engineering, Chemicals and Oil). The others were Industrial Holding, Mining Holding, Cash Assets, Furniture and Stores. The sectors that performed well were mostly related to the financial sector (Insurance, Banks and Financial Services), Pharmaceuticals, Fishing, Beverages and Hotels and light industry (Paper and Packaging, Food, Electronics). It would thus seem as if the 'sunrise' industries fare relatively better than the 'sunset' industries. The service sector and the light manufacturing sectors would appear to be performing better than the primary extraction sectors. This general trend is also reflected by the statistically significant differences found to exist between the broad sectorial sectors (Table 7).

Table 7 Mean performance rating by

\begin{tabular}{lc}
\hline Sector & Performance rating \\
\hline All & 178,1 \\
Mining & 224,0 \\
Finance & 151,3 \\
Industrial & 170,4 \\
\hline
\end{tabular}

$F=10,44 ; P=0,001$

\section{Discussion}

Although both our data and our analysis of these data are fairly superficial, they do nevertheless provide us with some basis for discussion, not so much in terms of providing conclusive evidence as in broadening the questions one may ask in relation to the concentration of economic power.

Our data suggest, in descriptive terms, that the South African economy is dominated by a few large corporations. These large corporations have large boards of directors and relatively higher proportions of multiple directors per board of directors than the smaller and 'independent' groups of and individual companies. This, in turn, implies a rather tight and cohesive network of directors which controls the largest proportion of wealth in the South African economy. The network of directors would seem to consist of smaller networks for groups of companies. The degree of cohesiveness of directors 
within each group of companies would appear to be extremely high. A far higher degree of cohesiveness would appear to exist in Afrikaans-dominated groups followed by English-dominated groups and only then by 'mixed' groups of companies.

A rather high degree of similarity would appear to exist within the elite in terms of educational and other 'pre-market' sociological factors. This, in turn, suggests that the elite is structured and that it organizes, however subconsciously, its own perpetuation. The pre-market factors for the Afrikaans and the English elite would, however, appear to be quite different. The biographical backgrounds of the English elite are strongly intertwined with the urban and elitist educational systems whereas the Afrikaans elite is biographically based in the rural and state school systems. These differences would however seem to become less relevant after entry into the elite has been established when the elite becomes far more homogeneous in terms of clubs and residential district. It can also be assumed that the children of the current Afrikaans business elite would be biographically very similar to their English counterparts.

Placing our findings on the white South African business elite into the context of the previous limited research on social mobility in South Africa, it would appear that, as in many of the countries of western Europe, there exists a considerable amount of relatively short-range mobility together with a higher degree of rigidity and recruitment at the extremes. As South Africa has industrialized whites have managed to move upwards intergenerationally. Now, with skills shortages and a slightly more 'open' attitude to racial mixing, a greater number of black people are also moving into higher categories of employment. However, although large percentage increases in black (and especially female) participation in certain oocupational categories have been recorded, absolute numbers and participation rates - relative to overall participation in the labour force - remain small. Indeed, the proportion of black people reaching elite positions remains negligible. Thus we have a situation in which children from privileged backgrounds possess substantial advantages in the competition for elite positions although with economic growth whites from humbler origins may also be reaching this level, while blacks are almost excluded from the process.

Although a proper study of social mobility in South Africa would require the analysis of data collected by means of a national survey, our scant evidence appears to suggest that the sociological argument relating to social mobility is, indeed, valid. With regard to the economic perspective, no consistent or strong relationship could be found to exist between performance rating and multiple directors. The inevitable conclusion of our analyses is that nepotism and group loyalty are, however subconsciously, more important to the elite than profitability and competitiveness. Within the white population of South Africa - which is often regarded as elitist in itself - we have a clearly defined business elite which has interests of its own to both protect and perpetuate.

All of this does not augur well for the process of black mobility into the higher echelons of business. Our study suggests that the concentration of economic power may present formidable obstacles to any attempts to transfer capital to blacks in a meaningful way. Similarly, our biographical profile of the business elite almost belies the possibility of blacks entering that elite in anything remotely like a critical mass. The most we can hope for is for the white business elite to open itself up to the existing black elite, to those black people who, because of their social origins or educational backgrounds, have formed an elite even in spite of the legal, social and potitical obstacles put in its way.

For the huge majority of black (and white) South Africans, the movement from rags to riches, in the absence of any fundamental change to the bases of power, represents no more than a pipe dream. As Heath (1981:77) states, 'Silver spoons continue to be distributed.........'

\section{References}

Allan, M. 1974. The structure of interorganizational elite cooptation: Interlocking Corporate Directorates. Am. Soc. Rev., vol.39, 393 - 406.

Du Plessis, P. 1978. Concentration of Economic Power in SA Manufacturing. J. Stud. Econ. Econometrics, vol.3. Glass, D. (ed.). 1954. Social Mobility in Britain. London, Routledge and Kegan Paul.

Hahlo, H. 1984. South African Company Law through the Cases. Fourth Edition. Cape Toun: Juta.

Heath, A. 1981. Social Mobility. Glasgow, Fontana.

Human, L. \& Hofmeyr, K. 1985. Black Managers in South African Organizations. Cape Town: Juta.

J.S.E. Johannesburg Stock Exchange Handbook 1984. Johannesburg.

Lipset, S. \& Bendix, R. 1959. Social Mobility in Industrial Society. Berkeley; University of California Press.

McGrath, M. 1977. Racial Income Distribution in South Africa. Durban, University of Natal (Interim Research Report, No. 2).

McGregor, R. 1984. Who Owns Whom. Fourth Edition. McGregor, Purdey.

McGregor, R. 1986. Investors Handbook Incorporating Who Ouns Whom. Sixth Edition. Mcgregor, Pundey.

Parkin, F. 1979. Marxism and Class Theory: A bourgeois critique. London: Tavistock.

Savage, M. 1984. Ownership and Control in South Africa: Themes in domination. Johannesburg: ASSA Conference.

Schneier, S.1983. Occupational Mobility among Blacks in South Africa. Cape Town, SALDRU, 1983 (Working Paper No.58.

Sunday Times Top 100 Companies Survey 1985. Johannesburg. Sunday Times.

Van der Merwe, H., Ashley, M.J., Charton, N.C.J. \& Huber, B.J. 1974. White South African Elites. Cape Town, Juta.

Westergaard, J. \& Resler, H. 1975. Class in a Capitalist Society: A Study of Contemporary Britain. Londoa: Heineman. 